\title{
OFD1 Gene
}

National Cancer Institute

\section{Source}

National Cancer Institute. OFD1 Gene. NCI Thesaurus. Code C75879.

This gene may play a role in the regulation of embryonic development. 